\title{
EDITORIAL
}

\section{A potência crítica da circulação midiática das imagens}

RuMoRes, revista científica online dedicada aos estudos de comunicação, linguagem e mídias traz, em sua vigésima quinta edição, o Dossiê "Políticas da crítica: formação e circulação em práticas midiáticas", com oito artigos que enfatizam a premência de um debate crítico sobre a mídia que seja estratégico, como proposto por Ismail Xavier; atualizado, como propõe Cláudio Rodrigues Coração; plural, como propõe Rose de Melo Rocha; interativo e público, como propõem, respectivamente, Felipe de Castro Muanis e Eduardo Paschoal; autêntico, como propõem Andrea Limberto e Fernanda Elouise Budag; profano, como propõe Vander Casaqui; e reincidente, como proposto por Cíntia Liesenberg no último artigo, voltado diretamente à questão da crítica midiática. A potência presente da crítica funda o Dossiê, organizado por Gislene da Silva (UFSC) e Rosana de Lima Soares (USP) e apresentado, nesta edição, no texto "Políticas da crítica: formação e circulação em práticas midiáticas".

Os textos do Dossiê privilegiam objetos imagéticos e artísticos, passando por produções cinematográficas, musicais e documentais para fazer ver sua presença muito concreta e efetiva e defender, para além da fruição estética, seus efeitos culturais, sociais e políticos. Trata-se de um debate atual e potente em torno dos objetos comunicacionais (especialmente produções audiovisuais), que está voltado para a crítica de sua circulação - travando com ela, inclusive, embates identitários, de formato e de gênero discursivo - e para as possibilidades de formação de uma esfera crítica e de constituição do público. Esse debate estende-se, ainda, aos demais textos da edição, que reúne sete artigos em face do mesmo desafio. 
Renato Luiz Pucci Junior e Fabiano Pereira de Souza buscam a ousadia narrativa na edição sonora de uma série televisiva em "O sound design da série Twin Peaks e a herança de Alan Splet", analisando até a temporada de 2017. Refletindo sobre como essa ousadia narrativa apercebe-se da presença do outro, "Sobre paisagens conhecidas e corpos anônimos: memórias fotográficas do fluxo migratório no Mediterrâneo", de Ana Carolina Lima Santos e Rafael Tassi Teixeira, analisa fotografias jornalísticas que retratam africanos e médio-orientais tentando cruzar o mar Mediterrâneo.

Quem é o sujeito da imagem? O que a imagem faz por ele? Wagner Souza e Silva e Carolina Vilaverde Lopes constatam que subjetividades são tomadas na mediação das identidades e das relações sociais pela tecnologia, restando a afirmação de que "Agora somos imagens: fotografia e a hibridização entre humanos e telas". Alguns cineastas operam ressignificações, que Marcelo de Lima e Luiz Antonio Mousinho procuram destacar nos filmes de Pedro Almodóvar e de Joseph Mankiewicz pelas lentes do conceito de dialogismo em "O cinema enquanto locus dialógico: ressignificações entre Tudo sobre minha mãe (1999) e A malvada (1950)".

Passando do âmbito ficcional ao jornalístico e documental, é ainda mais necessário situar o juízo ético que sustenta a tomada dos sujeitos em imagens, como pretendem Camila Hartmann e Ada Cristina Machado em "A midiatização de um juízo político: responsabilidade editorial nas capas de revistas semanais brasileiras", analisando capas de revistas com fotografias da presidenta Dilma Rousseff no dia posterior ao processo de votação de impeachment na Câmara dos Deputados.

Se há uma saída consonantemente ética e moral, há também aquela pelo humor, dissonante e desafiadora de valores no abuso da ironia e do sarcasmo. Em "Para fazer rir na TV: fabulação narrativa do humor entre as teorias da disjunção e da disparidade", Wanderley Anchieta estuda os mecanismos para a geração do riso considerando as séries Arrested development, Friends, Studio 60. E, na sequência deste olhar estruturado para o humor, Bruno Menezes Andrade Guimarães questiona se ele colabora para um menor dogmatismo e 
maior pluralidade religiosa, observando um canal do YouTube em "Humor e religião: Porta dos fundos e a crítica ao monoteísmo cristão".

Com este segundo Dossiê sobre crítica de mídia, RuMoRes busca firmar a atualidade deste debate por meio da recuperação de diversas correntes teóricas que sustentam historicamente o pensamento crítico; da atualização necessária e relevante de seus preceitos; da aplicação de critérios para a análise de produções midiáticas atuais; e, ainda, do reforço de um campo de estudos para a crítica de mídia em âmbito acadêmico.

Em tempos de aguda crise política e institucional no país, que afeta diretamente a todos nós, especialmente aqueles que estão em universidades, centros de pesquisa e instituições de produção artística e cultural, esperamos que as reflexões possam suscitar debates produtivos sobre a realidade e as possíveis formas de intervenção em nossos lugares de inserção. Que o espaço acadêmico contribua para a consolidação de posicionamentos críticos e engajados na transformação social e na construção de uma sociedade cada vez mais democrática e igualitária. Boas leituras a todas e todos!

Rosana de Lima Soares Andrea Limberto junho de 2019 